\title{
Effect of Neem Azal (Azadirachta indica) Extracts on the Mortality and Fecundity of Hyalomma dromedraii Females
}

\author{
Laila M. I. Oyoun ; Ebtesam M. Almatha ${ }^{l^{* *}}$ and Hanan S. M. Gabr \\ *Zoology Dept., Faculty of Agric., Cairo Univ., Egypt. laila_laila12342000@yahoo.com \\ ${ }^{* *}$ Zoology Dept., Faculty of Science for Girls, King Faisal Univ., Saudi Arabia.
}

\begin{abstract}
Effect of the two Neem, Azadirachta indica extracts, Neem Azal F and T on fed Hylomma dromedarii (Koch) females and their fecundity under laboratory conditions was studied. Females mortality rate increased gradually as Neem extract concentration increased (i.e. 0.2 to $0.8 \%$ ). The $\mathrm{LC}_{50}$ values were 0.8 and $0.6 \%$ post treatment of Neem $\mathrm{Azal} F$ and $\mathrm{T}$, respectively at the $11^{\text {th }}$ day. Treated females laid fewer eggs than those of the control: The concentrations $0.2,0.4,0.6$ and $0.8 \%$ of Neem extract decreased the percentage of hatching eggs from (46.38 to 10.56) and (35.4 to 8.42 ) and increased the larval mortality rate from (56.46 to 80.34) and from 87.15 to 94.53 for Neem Azal $F$ and $\mathrm{T}$, respectively.
\end{abstract}

Key Words: Hyalomma dromedraii, Azadirachta indica, Plant extract, Fecundity, Hatchability.

\section{INTRODUCTION}

Ticks are economically important pests all over the world. Tick species are vectors of different animal and human disease agents such as bacteria, protozoa, rickettsia and viruses (Darwish \& Hoogstraal 1981 and Pegram et al., 1988).

Diseases such as lyme, borreliosis and tick-borne encephalitis in humans, and spirochetosis, babesiosis and theileriosis in domestic animals are known to be transmitted by ticks (Madbouly et. al., 1990, Oyoun et. al., (1996-1998), and El Kammah et. al., 2001 \& 2007)

Tick infestation is mainly reduced by spraying or dipping the animals in chemical acaricides. These control methods may lead to environmental pollution and toxicity to animal tissues. Therefore, vaccination, immunological methods, safe environment and human resources protection methods of biological control or none chemical control must be utilized for tick control (Sivaramakrishnan et. al,. 1996, Abdel Wahab et. al., 2000 \& 2004, El Kammah \& Abdel Wahab 2003, Sayed et. al., 2004, and El Kammah et. al., 2006). The use of predators, parasites, active chemicals from natural source of plants, fungi and bacteria is what ment by non chemicals control, (Kaya \& Hassan 2000 and El Kammah \& Oyoun 2007).

The aim of this study was to control the camel tick Hyalomma dromedarii (Koch) which also known to infest different farm animals using Neem plant extract products.

\section{MATERIALS AND METHODS}

Engorged $H$. dromedarii females were collected from camels in Damam region (Kingdom of Saudi
Arabia) from September to December 2007 and identified according to Hoogstraal et al., 1981. Two chemical extracts from Neem plants Azadirachta indica seeds: Neem Azal $\mathrm{F}$ (cotains 5\% Azadirachtin) and Neem Azal $\mathrm{T}$ (contains 1\% Azadirachtin) were applied against $H$. dromedraii females and eggs. Experiments were carried out by dipping females and eggs in different concentrations of these Neem extracts for 30 seconds then dried on filter papers. The control was conducted by dipping similar stages in water for 30 seconds. Tested concentrations of each Neem extract were 0.2, 0.4, 0.6 and $0.8 \%$. Three replicates were applied for each concentration. Ten treated and control females and eggs were kept in rearing tubes, incubated at $30^{\circ} \mathrm{C}$ and $75 \%$ R.H. and observed daily for oviposition, longevity and hatchability.

\section{RESULTS AND DISCUSSION}

The effect of two Neem extracts. Neem Azal F(NAF) and Neem Azal T(NAT), applied on fed $H$. dromedurii females and their fecundity under laboratory conditions, are shown in Tables $1 \& 2$. No effect of NAF or NAT was observed on the mortality rates of $H$. dromedarii females till the $4^{\text {th }}$ day of treatment. NAT had stronger effect, especially since the $7^{\text {th }}$ and $9^{\text {th }}$ days of treatment, but equalized after the $11^{\text {th }}$ and $13^{\text {th }}$ days of treatment.

Abdel Shafy (2000) found that Boophelus anmulatus (Say) females mortality was recorded after 7 and 9 days of treatment with NAT and NAF respectively. Similarly to $H$. dromedarii mortality rate increased gradually from lower concentration to higher ones and from the $7^{\text {th }}$ day until the $13^{\text {th }}$ day.

Table 2, shows that the effect of both Neem extracts on oviposition of $H$. dromedarii proved that, all recovered treated females laid fewer eggs 
Table (1): Effect of Neem Azal F and Neem Azal T on mortality rate of the Hyalomma dromedarii females under laboratory condition

\begin{tabular}{|c|c|c|c|c|c|c|c|c|c|}
\hline \multirow{3}{*}{$\begin{array}{c}\text { Days } \\
\text { Post } \\
\text { Treatment }\end{array}$} & \multicolumn{9}{|c|}{ Mortality Percent } \\
\hline & \multicolumn{4}{|c|}{ Neem Azal F Concentrations } & \multicolumn{4}{|c|}{ Neem Azal T Concentrations } & \multirow{2}{*}{ Control } \\
\hline & $0.2 \%$ & $0.4 \%$ & $0.6 \%$ & $0.8 \%$ & $0.2 \%$ & $0.4 \%$ & $0.6 \%$ & $0.8 \%$ & \\
\hline $1^{\text {th }}$ & 0 & 0 & 0 & 0 & 0 & 0 & 0 & 0 & 0 \\
\hline $2^{\text {nd }}$ & 0 & 0 & 0 & 0 & 0 & 0 & 0 & 0 & 0 \\
\hline $3^{\text {rd }}$ & 0 & 0 & 0 & 0 & 0 & 0 & 0 & 0 & 0 \\
\hline $4^{\text {th }}$ & 0 & 0 & 0 & 0 & 0 & 0 & 0 & 0 & 0 \\
\hline $5^{\text {th }}$ & 0 & 0 & 0 & $4.56 \pm 2.53$ & 0 & $2.12 \pm 2.1$ & 3.421 .31 & $6.20 \pm 0.11$ & () \\
\hline $7^{\text {th }}$ & 0 & $3.1 \pm 1.81$ & $3.42 \pm 2.45$ & $5.36 \pm 4.22$ & $3.11 \pm 2.12$ & $4.64 \pm 3.22$ & $9.4 \pm 3.43$ & $10.54 \pm 4.32$ & 0 \\
\hline $9^{\text {th }}$ & 0 & $4.31 \pm 3.21$ & $5.45 \pm 2.51$ & $6.32 \pm 3.53$ & $9.13 \pm 3.21$ & $10.11 \pm 4.41$ & $11.11 \pm 4.31$ & $12.5 \pm 3.3$ & $4.01 \pm 2.51$ \\
\hline $11^{\mathrm{th}}$ & $35.91 \pm 11.3$ & $44.32 \pm 9.21$ & $40.42 \pm 8.44$ & $50.81 \pm 9.71$ & $35.43 \pm 10.2$ & $41.51 \pm 9.45$ & $50.72 \pm 10.5$ & $54.63 \pm 8.34$ & $24.68 \pm 5.44$ \\
\hline $13^{\text {th }}$ & $60 \pm 9.8$ & $56.4 \pm 10.2$ & $66.4 \pm 11.2$ & $67.32 \pm 8.41$ & $66.23 \pm 9.42$ & $67.12 \pm 8.23$ & $66.54 \pm 10.7$ & $68.71 \pm 11.2$ & $45.31 \pm 6.87$ \\
\hline
\end{tabular}

Tabel (2): Effect of Neem Azal F and Neem Azal T on the fecundity of Hyalomma dromedarii female under laboratory condition.

\begin{tabular}{cccccccccc}
\hline & \multicolumn{7}{c}{ Number of eggs/ femal( mean \pm sd ) } \\
\cline { 2 - 8 } Days & \multicolumn{7}{c}{ Neem Azal F concentrations } & \multicolumn{7}{c}{ Neem Azal T concentrations } & Control \\
\cline { 2 - 8 } & $0.2 \%$ & $0.4 \%$ & $0.6 \%$ & $0.8 \%$ & $0.2 \%$ & $0.4 \%$ & $0.6 \%$ & $0.8 \%$ \\
\hline $1^{\text {st }}$ & $60 \pm 50$ & $47 \pm 73$ & $57 \pm 64$ & $12 \pm 25$ & $12 \pm 25$ & $10 \pm 15$ & $10 \pm 11$ & $14 \pm 25$ & $100 \pm 46$ \\
$2^{\text {nd }}$ & $310 \pm 120$ & $230 \pm 130$ & $360 \pm 260$ & $150 \pm 210$ & $45 \pm 20$ & $80 \pm 45$ & $140 \pm 102$ & $25 \pm 30$ & $350 \pm 210$ \\
$3^{\text {td }}$ & $1230 \pm 570$ & $1120 \pm 560$ & $1320 \pm 430$ & $1100 \pm 940$ & $1006 \pm 810$ & $1154 \pm 802$ & $1200 \pm 780$ & $1001 \pm 601$ & $1400 \pm 450$ \\
$5^{\text {th }}$ & $7800 \pm 1005$ & $6466 \pm 890$ & $5644 \pm 950$ & $6931 \pm 1002$ & $8110 \pm 540$ & $7921 \pm 420$ & $7820 \pm 1220$ & $6831 \pm 110$ & $8503 \pm 1320$ \\
$7^{\text {th }}$ & $5836 \pm 622$ & $5870 \pm 432$ & $5600 \pm 823$ & $4751 \pm 745$ & $5600 \pm 833$ & $5230 \pm 941$ & $4400 \pm 674$ & $4132 \pm 689$ & $5920 \pm 720$ \\
$9^{\text {th }}$ & $3250 \pm 102$ & $3100 \pm 230$ & $2970 \pm 420$ & $2150 \pm 320$ & $2220 \pm 210$ & $1563 \pm 310$ & $1320 \pm 390$ & $1123 \pm 450$ & $3140 \pm 520$ \\
$11^{\text {th }}$ & $820 \pm 262$ & $740 \pm 340$ & $650 \pm 260$ & $540 \pm 201$ & $1020 \pm 305$ & $950 \pm 190$ & $840 \pm 180$ & $720 \pm 100$ & $954 \pm 255$ \\
$13^{\text {th }}$ & $320 \pm 84$ & $220 \pm 82$ & $110 \pm 72$ & $98 \pm 75$ & $230 \pm 64$ & $190 \pm 90$ & $180 \pm 110$ & $120 \pm 100$ & $240 \pm 60$ \\
Total & $19626 \pm 1000$ & $17793 \pm 911$ & $16711 \pm 813$ & $15732 \pm 1200$ & $18243 \pm 1110$ & $17098 \pm 1430$ & $16010 \pm 940$ & $13966 \pm 1210$ & $20607 \pm 2210$ \\
\hline
\end{tabular}

Table 3: Effect of different concentrations of Neem Azal F and Neem Azal T on Hyalomma dromedarii eggs hatchability and mortality of unfed larvae under laboratory condition.

\begin{tabular}{|c|c|c|c|c|c|}
\hline \multirow{3}{*}{$\begin{array}{c}\text { Concentration } \\
\%\end{array}$} & \multicolumn{5}{|c|}{ Hatching and mortality $\%$} \\
\hline & \multicolumn{3}{|c|}{ Neem Azal FMean \pm sd } & \multicolumn{2}{|c|}{ Neem Azal TMean $=$ sd } \\
\hline & $\cdot$ & Hatched eggs & Dead larvae $\%$ & Hatched eges & Dear larrae" \\
\hline 0.2 & & $46.38 \pm 11.33$ & $56.46 \pm 12.39$ & $\because \cdots 140$ & $\because \cdots 3=3$ \\
\hline 0.4 & & $38.45 \pm 10.32$ & $65.34 \pm 13.27$ & $30.65+1: 5 !$ & $70.32 \ldots 17.92$ \\
\hline 0.6 & & $20.65 \pm 5.45$ & $78.43 \pm 10.53$ & $25.35 \pm 7.51$ & $80.44 \pm 19.45$ \\
\hline 0.8 & & $10.56 \pm 2.34$ & $80.34 \pm 15.32$ & $8.42 \pm 2.33$ & $94.53 \pm 21.31$ \\
\hline Conter: & & $100+0$ & $24.45 \pm 4.33$ & $100 \pm: 0$ & $35.34 \pm 8.34$ \\
\hline
\end{tabular}


compared with those of the control. The number of eggs increased from the $1^{\text {st }}$ until the $5^{\text {th }}$ day for each extract then decreased from the $7^{\text {th }}$ day until $13^{\text {th }}$ as in the control. This result agrees with those of Abdel Shafy (2000), who recoded the mortality rate after 7 and 9 days post treatment in NAT and NAF respectively on $B$. anmulatus females. The decrease is distinct in the total number of eggs under $0.8 \%$ concentration of the two extracts compared with the others.

Several trials were conducted successfully against $B$. microplus in the field or under laboratory condition (Williams, 1991 \& 1993). However, the Veem extract did not show significant effect on $B$. unnulatus (Abdel Shafy 2000).

Effect of Neem extracts on embryogensis of $H$. dromedarii eggs is shown in Table 3. The percentage of hatching eggs treated with $0.2 \%$ concentration was significantly higher than those treated with the others and the least was that of NAF and NAT at $0.8 \%$ concentration. Similar results were observed by Abdel Shafy (2000) who treated $B$. annulatus eggs with Bio Dux. The $\mathrm{LC}_{50}$ values of Neem Azal $F$ and $T$ were 0.8 and 0.9 respectiely. The concentrations $0.2,0.4,0.6$ and $0.8 \%$ of NAF and NAT decreased percentage of hatching eggs and increased larvae mortality rate. The mortality rate of hatched larvae recorded 56.4, 65.3, 78.4 and $80.34 \%$ treated with $0.2,0.4,0.6$ and $0.8 \% \mathrm{NAF}$ and 87.1 , $70.3,80.4$ and $94.5 \%$ under the same NAT concentrations, respectively. These results agree with those of Davey and Ahrens (1983), while Carrol et. al., (1989) found that the extract of myrrh was less effective as a larvicide against Amblyomma americamum (koch).

Finally, it could be concluded that using Neem extracts of both NAT and NAF to control the camel tick $H$. dromedarii with concentration $0.6 \%$ and 0.8 $\%$ are effective against all stages which encourage the need for further studies.

\section{REFERENCES}

Abdel Shafy, S. A. 2000. Microbiological and control studies on ticks infestating farm animals and poultry. Ph. D. Fac. Agr. Cairo Univ., 187 PP.

Abdel-Wahab, K. S. E., M. Ali and K. M. El Kammah 2004. Approaches towards developing a vaccine against Boophilus annulatus (AcariIxodidae): Identification of a gene for expression of gut cell surface proteins. Arab. J. Biotech. $7(2): 283-288$.

Abdel-Wahab, K. S., E. G. Heial and K. M. El Kammah, 2000. Boophilus annulatus (Acari:
Ixodidae) cattle-acquired humoral and cellmediated immunity against tich gut and salivary gland antigens. Int. J. Acarol. $26(+1::-9-484$.

Carrol, J . F.; Maradufn A. and Warthen. I. D. I. 1989. An extract of Commiphores errincted: arepellent and toxicant against tistis. Entomologia Experimentalis et Appliata. $三 3121$. 111-116.

Darwish, M. and Hoogstraal, H 1981. Arborirus infectinghumans and lower animals in Egypt: $A$ review of thirty years of research. J. Egy. Public Health Association. 1 (1-2): 1- 112.

Davey, P. B. and Ahrens, H. 1983. Control of Boophilus ticks on heifers with tow pyrethroids applied as spraying. Ann. J. Vet. Res. 45 (5): $1008-1010$.

El Kammah, K. M. and K. S. E. Abdel Wahab. 2003. Studies on the immune defence of chickens and cattle against Argas persicus and Boophilus annulatus ticks (acari: ixodoidea. 2nd African Acarology Symposium Dec. 2001: Insect Sci. Applic. 23 (1): 75-83.

EI Kammah, K. M., L. M. I. Oyoun, G. A. Kady and S. Abdel Shafy, 2001. Investigation of blood parasites in livestock infested with argasid and ixodid ticks in Egypt. J. Egypt. Soc. Parasitol. 31(2): $365-371$.

EL Kammah, K. M., K. S. E. Abdel Wahab, L. M. I. Oyoun and H. S. M. Gabr. 2006. Studies on Hyalomma dromedarii (acari: ixodidae) salivary glands and gut immunogenecity. Arab. J. Biotech. 9(1): 41-50

El Kammah, K. M. And L. M. I. Oyoun. 2007. Entomopathogenic fungus as a biocontrol agent against the cattle tick Boophilus anmulatus (Say) (Acari; Ixodidae). J. Egypt. Soc. Acarology 1: 45-47.

El Kammah, K. M., L. M. I. Oyoun, and S. A. Abdel Shafy. 2007. Detection of microorganisms in the saliva and midgut of different tick species (Acri: Ixodoidea) in Egypt. i. Egypt. Soc. Parasitol. 37 (2): 533-539.

Hoogstraal, H., Y., Wasff and W.W. Buttiker. 1981. Ticks acarina of Saudia Arabia fam: Argasidae, Ixodidae. Fauna of Saudi Arabia (3):25- - 1 10.

Kaaya, G. P. and Hassan S. 2000 . Entomogenous fungi as promising biopesticides for tick control. Exp. and App. Acarology. (24): 913-926.

Madbouly, M. H.. K. M. El Kammah. L. I. Oyoun and S. M. Habeeb. 1990. The Interrefutionships of the avian spirochetosis Borrelia anserina (Sakaroff 1891) and their tick vectors. Egypt. J. Appl. Sci., 5 (8): 380 - 391.

Oyoun, L. M. I., H. M. Madbouly, K. M. El Kammah and S. A. Ei Shafy 1996-1998. The role of ticks and the occurrence of babesia and theileria in domestic animals. Bull. Zool. Soc. Egypt, 44: $1-7$. 
Pegram, R. G., H. G. B. Chizyuka, E .T . Mawase, and Z. Zekle. 1988. Production economics in world wide animal commodities subject to disease transmission and infestation by acarines. The economic impact of cattle tick control in Central Africa. Paper presented at the National symposium on Theileriosis, 17-19 October 1988 Lusaka. Zambia .

Sayed, M. A., K. M. El Kammah, and Z. El-Fiky. 2004. A preliminary study on the DNA-vaccine for chicken protection against tick Argas persicus (Oken, 1818) Arab. J. Biotech. $7(2):$ 273-282.

Sivaramakrisknan, S., K. S. Kumar, D. Jeyabalan, R. Babu, N. S. Raja, and K. Murugan. 1996. The effect of mixtures of Neem, Eucalyptus and Pongamia Oils on the mortality and biochemical profiles of the tick Boophilus microplus (Acari: Ixodidae). Indian J. Environ\& Toxical. $6(2): 85-86$.

Williams, L. A. D. 1991. Acaicidal activity of five marine algae extracts on female Boopheus microplus (Acari: Ixodidae) Fla Entomol. 74(3): 404- 408.

Williams, L. A. D. 1993. Adverse effect of extracts of Artocarpus attilis Park. and Azadirachta indica ( $A$. juss) on the reproductive physiology of the adult female tick Boophilus (conest) Invet, Repord \& develop. 23 (2-3); 159 -164. 